\title{
Fruits of the Brazilian Atlantic Forest: allying biodiversity conservation and food security
}

\author{
ROBERTA G. DE SOUZA ${ }^{1}$, MAURÍCIO L. DAN ${ }^{2}$, MARISTELA A.DIAS-GUIMARÃES ${ }^{3}$, \\ LORENA A.O.P. GUIMARÃES ${ }^{2}$ and JOÃO MARCELO A. BRAGA ${ }^{4}$
}

\author{
${ }^{1}$ Centro de Referência em Soberania e Segurança Alimentar e Nutricional/CPDA/UFRRJ, \\ Av. Presidente Vargas, 417, $10^{\circ}$ andar, 20071-003 Rio de Janeiro, RJ, Brazil \\ ${ }^{2}$ Instituto Capixaba de Pesquisa, Assistência Técnica e Extensão Rural/INCAPER, CPDI Sul, Fazenda \\ Experimental Bananal do Norte, Km 2.5, Pacotuba, 29323-000 Cachoeiro de Itapemirim, ES, Brazil \\ ${ }^{3}$ Instituto Federal de Educação, Ciência e Tecnologia Goiano, Campus Iporá, Av. \\ Oeste, 350, Loteamento Parque União, 76200-000 Iporá, GO, Brazil \\ ${ }^{4}$ Instituto de Pesquisas Jardim Botânico do Rio de Janeiro, Rua Pacheco Leão, 915, 22460-030 Rio de Janeiro, RJ, Brazil
}

Manuscript received on May 31, 2017; accepted for publication on April 30, 2018

\begin{abstract}
Supplying food to growing human populations without depleting natural resources is a challenge for modern human societies. Considering this, the present study has addressed the use of native arboreal species as sources of food for rural populations in the Brazilian Atlantic Forest. The aim was to reveal species composition of edible plants, as well as to evaluate the practices used to manage and conserve them. Ethnobotanical indices show the importance of many native trees as local sources of fruits while highlighting the preponderance of the Myrtaceae family. Conservation analysis allowed to identify Campomanesia hirsuta Gardner and Plinia edulis (Vell.) Sobral as being of high Biological Value and Conservation Priority. In spite of that, the local management practices of native fruits appear to be sustainable and contribute to the maintenance and dissemination of valuable species. These results suggest a number of recommended future conservation actions and show the potential of Myrtaceae species for future agronomical development in Neotropical regions.
\end{abstract}

Key words: Agrodiversity, Myrtaceae, native species, quantitative ethnobotany, sustainable management.

\section{INTRODUCTION}

The relationship between food security and the conservation of biodiversity is one of the most important of contemporary paradigms. The Convention on Biological Diversity (CBD), regarded as a landmark in the history of conservation efforts, stresses that the sustainable use of biodiversity goes hand in hand with

Correspondence to: Lorena A. de Oliveira Prata Guimarães

E-mail: lorena.prata@hotmail.com human well-being (United Nations 1992). The International Treaty on Plant Genetic Resources for Food and Agriculture (ITPGRFA) emphasizes the importance of protecting wild resources in order to ensure food security worldwide (FAO 2009).

The current concern with the diversification of human dietary resources is due largely to the challenges posed by climate change and the rapid growth of the world's population. In response to climate change and the rise of crop pests and 
diseases, the use of temperate climate cultivars in tropical regions can become very costly (Frison 2011). Native species represent a source of genetic variability with the magnitude, complexity and adaptability necessary for tropical and subtropical conditions. Coupled with that, the intensification of family-based agriculture is seen as one way to enhance local food sovereignty (FAO 2009). Thus, the diversification of small-scale farming of native cultivars and the sustainable harvesting of plants in forest remnants could boost food security in developing countries (Kinupp and Barros 2010). FAO (Food and Agriculture Organization of the United Nations) defines Non-Timber Forest Products (NTFP) as "products of biological origin other than wood derived from forests, other wooded land and trees outside forests" (FAO 1995). Often, the concept implies direct use, as food, medicine or construction material, but indirect uses are equally relevant, such as for the genetic improvement of conventional cultivars, environmental conservation and social use. FAO data (1995) show that about $80 \%$ of the populations of developing countries use forest products to meet their nutritional and health needs as well as to generate income. According to Aldana (2002), around 500 million people living close to tropical forests use forest resources in their everyday lives. Nowadays, these many sustainable uses of NTFP stand out to discourage deforestation. In Brazil, the contradiction between a high natural biodiversity and the foreign origin of most cultivated plants deserves consideration. The use of alien crops is usually not derived from the intrinsic superiority of these plants, but from a long coevolutionary process between men and cultivars. The issue involves historical, behavioral and environmental aspects and suggests the potential use of many tropical plants when conditioned to similar processes of domestication (Sereno et al. 2008).

According to Ministry of Environment (2009) the most important forest products in Brazil, in terms of trading volume, are "babaçu" seeds (Attalea speciosa Mart. ex Spreng), various natural waxes from the caatinga forest, "pequi" seeds (Caryocar brasiliense Cambess.), "copaiba" oil (Copaifera langsdorffii Desf.), and "aça'́" berries (Euterpe oleracea Mart.), most of them of Amazonian or Northeastern origin. In the Atlantic Forest, a lower volume of native products are used and traded. Due to urban and agricultural expansion, there are few remaining fragments of this rainforest, which harbor a great number of rare and endangered species (Mittermeier et al. 1999). Nonetheless, a variety of native seeds, fruits and fibers have local importance and are used by surrounding communities, stressing the need for research on how those traditional practices might affect current conservation status.

Most ethnobotanical studies in the Brazilian Atlantic Forest were conducted among traditional coastal populations, called caiçaras, and point out the relevance of native plants. For example, Hanazaki et al. (2000) found that native plants accounted for more than fifty percent of the species used by two such coastal communities. In Borges and Peixoto (2009), the handicraft use category (construction/technology) accounted for most citations, all of which referred to native trees. Giraldi and Hanazaki (2014) show the importance of forest resources for food security. Although local communities have experienced recent major changes such as urbanization, tourism and limitations in protected areas by law, local plants account for eight to twelve percent of local diets. In another study, informants considered as useful all of the forty-two plant species found in a nearby forest fragment (Cruz da Cunha and Albuquerque 2006).

In such situations, priority for conservation and sustainable management must be given to those plants that are rare and/or subjected to detrimental management practices (Tardío and Pardo-deSantayana 2008). Targeted studies are needed to 
evaluate which kind of uses are sustainable, both in ecological and social terms. Thus, this article aims at characterizing the use of native trees by a rural population of the Atlantic Forest in Espírito Santo, Brazil. The objective is to answer the following questions: Which native arboreal species are used? Which are the most important species for human food? Which are their management practices? Which of these species deserve conservation measures? The answers will not only guide future conservation actions, but will also indicate potential genetic resources for future agronomic development in tropical regions.

\section{MATERIALS AND METHODS}

\section{THE MOUNTAIN REGION OF ESPÍRITO SANTO}

This study was developed in the forested mountain region of Espírito Santo State, located in Southeastern Brazil. The area occupies approximately $7500 \mathrm{Km}^{2}$, including thirteen municipalities such as Afonso Cláudio, Conceição do Castelo, Domingos Martins, and Venda Nova do Imigrante (between coordinates $20^{\circ} 00^{\prime} 15^{\prime \prime}$ $20^{\circ} 33^{\prime} 23^{\prime \prime} \mathrm{S}$ and $40^{\circ} 35^{\prime} 09^{\prime \prime}-41^{\circ} 15^{\prime} 39^{\prime \prime} \mathrm{S}$ ). This is known as the "Territory of Mountains and Waters" by the Ministry of Agricultural Development, thus defined on the basis of its cultural, economic and environmental characteristics.

The terrain is rough, composed mostly of Cambisols and Ferralsols soil types (IUSS Working Group WRB 2006). Altitudes range between 300 and $1100 \mathrm{~m}$. The climate is Am type (Peel et al. 2007) which is hot tropical, without a winter dry season. At the regional level, the high altitudes cause the relatively low temperatures, as well as high levels of rainfall (average $=1350 \mathrm{~mm} /$ year, Feitoza et al. 1999). Watersheds arising in the region supply more than $70 \%$ of the water used by the State's capital city, Vitória, which highlights the importance of the forest cover of the region.
The region is located in the Atlantic Forest domain, subtypes Dense Montane and SubMontane Ombrophilous Forest (Veloso et al. 1991), composed of moist, evergreen rainforests. According to the Atlas of Atlantic Forest Remnants for 2005-2008 (Fundação SOS Mata Atlântica and INPE 2009), the mountain region has the largest forest cover remaining in Espírito Santo, with up to $35 \%$ of the original vegetation. Part of it is protected in eight natural reserves, of which two are public: Pedra Azul and Forno Grande State Parks, while the other six were created by private initiative.

Most of the current population is composed of the descendents of Italian and German immigrants from the late XIX century. In the rural zones, cultural practices include the use of fire to clear the land for agriculture. Rural development is based on medium and small family farms which play an important role in food production. Although valleys are densely occupied by households and plantations, the highest and steepest areas are relatively preserved under forest cover. In this scenario, most families have forest fragments in their properties and together, these private, unprotected fragments account for most remnants of native vegetation (IPEMA 2005).

\section{DATA COLLECTION AND ANALYSIS}

The use of native arboreal species was studied through interviews with key informants, botanical identification and quantitative data analysis, as described below.

\section{Interviews with key informants}

Twenty key informants were selected on the basis of their knowledge of the uses of native arboreal resources in the study area as recognized by local professionals from the Espírito Santo Institute of Research and Rural Assistance (INCAPER). These professionals work in daily contact with agriculturalists and are part of extensive local 
networks. All individuals were interviewed between March and July 2014. They were informed in advance on objectives of the research and had agreed to collaborate.

Interviews were based on semi-structured questionnaires aimed at accessing the most frequently used species and the use categories and management practices assigned to each species, including the vegetative parts involved (i.e. fruits, leaves, roots, etc) and the consequences for the original plant (i.e. the harvesting risk). This theoretical information was complemented by the "walking in the woods" method (Phillips and Gentry 1993 a, b), in which the informant and the interviewer talk about the use of plants they encounter around the rural and forest landscape. Only native arboreal plants were considered during this study.

Preliminary species identification was performed in loco. When fertile individuals were found, a sample was collected for deposit and identification in the Rio de Janeiro Botanical Garden (RB).

\section{Analysis of quantitative data}

The data was analyzed using quantitative ethnobotanical indices, allowing estimation of relative importance of species and botanical families. The use-value of each species cited was calculated using the formula below, adapted from Phillips and Gentry (1993a) by Rossato et al. (1999) for only one interview with each informant.

$$
U V S=\sum_{i}^{n} U_{s i} / n
$$

where UVs $=$ species use value $\mathrm{s}$; Usi $=$ is the number of uses for species $\mathrm{s}$ mentioned by each informant; and $\mathrm{n}=$ the total number of informants.

The use value of botanical families was calculated according to the methodology of Phillips and Gentry (1993a):

$$
F U V=\sum U V s / n f
$$

where $\mathrm{FUV}=$ is the family use value, $\mathrm{VUs}=$ is the use value of species in the family and; $n f=$ is the number of species in the family.

The degree of Conservation Priority of each species was established using a methodology adapted from Dzerefos and Witkowski (2001) and Crepaldi and Peixoto (2010) (Table I). The Biological Value of a species is determined both by its Extinction risk (E) and by its Distribution (D) rather by the density of plants in the local natural reserve as in Dzerefos and Witkowski (2001). This adaptation is justified by the larger spatial scale of the present study, at the regional rather than the local level. The data on extinction risk and distribution are from secondary sources such as Forzza et al. 2010 and international, national and regional lists of endangered species (World Conservation Monitoring Centre 1998, Simonelli and Fraga 2007, Martinelli and Moraes 2013).

The following parameters are derived from the criteria in Table I:

1) Biological value $(B)=(0.5(D)+0.5(E)) \times 10$ (adapted from Dzerefos and Witkowski 2001) Where $\mathrm{E}=$ Extinction risk and $\mathrm{D}=$ Distribution.

2) Use-risk $(\mathrm{UR})=(0.5(\mathrm{H})+0.5(\mathrm{UV})) \times 10$

Where $\mathrm{H}=$ Harvesting risk and $\mathrm{UV}=$ use-value, which is determined by the largest value L (local use) or V (use-diversity) (Mander et al. 1997 as cited by Dzerefos and Witkowski 2001)

3) Conservation Priority $(\mathrm{PC})=0.5(\mathrm{~B})+0.5$ (UR)

Category 1 (all species with rating $\geq 85$ ) require conservation priority and should not be harvested until a management regime is instituted.

Category 2 (all species with rating between 85 and $60)$ can be harvested moderately.

Category 3 (all species with rating $\leq 60$ ) are appropriate for harvesting. 
TABLE I

Scoring criteria employed in the classification of species according to conservation priority.

\begin{tabular}{|c|c|}
\hline Criteria & Points \\
\hline \multicolumn{2}{|l|}{ a. Distribution (D) } \\
\hline Endemic to the formation (Ombrophilous forest) & 10 \\
\hline Endemic to the biome & 7 \\
\hline Endemic to the country & 4 \\
\hline Native to the country & 1 \\
\hline \multicolumn{2}{|l|}{ b. Extinction risk (E) } \\
\hline Endangered or critically endangered & 10 \\
\hline Vulnerable & 7 \\
\hline Near threatened & 4 \\
\hline Not listed or least concern & 1 \\
\hline \multicolumn{2}{|l|}{ c. Harvesting risk $(\mathrm{H})$} \\
\hline $\begin{array}{l}\text { Destructive collection of the entire plant, bulbs } \\
\text { and stalks, removal of cork-tissue, bark, or roots. } \\
\text { Represents the removal of the individual and its } \\
\text { future offspring from the population }\end{array}$ & 10 \\
\hline $\begin{array}{l}\text { Removal of the perennial structures, such as roots } \\
\text { and bark without causing }\end{array}$ & 7 \\
\hline \multicolumn{2}{|l|}{ individual mortality } \\
\hline $\begin{array}{l}\text { Removal of the permanent aerial structures such } \\
\text { as leaves, stems, and sap, affecting plant energetic } \\
\text { investments, survival, and reproductive success }\end{array}$ & 4 \\
\hline $\begin{array}{l}\text { Removal of transitory aerial structures, such as } \\
\text { flowers and fruits. Population regeneration may be } \\
\text { altered in the long-term as these produce or hold } \\
\text { seeds but the individual plant, particularly where } \\
\text { asexual reproduction is possible, is not affected }\end{array}$ & 1 \\
\hline \multicolumn{2}{|l|}{ d. Local use (L) } \\
\hline High (cited by more than $20 \%$ of the informants) & 10 \\
\hline Moderately high (10-20\%) & 7 \\
\hline Moderately low ( $<10 \%$ of all citations) & 4 \\
\hline Low (only referred to in the literature) & 1 \\
\hline \multicolumn{2}{|l|}{ e. Use-diversity (V) } \\
\hline For each use, add one point to maximum of & 10 \\
\hline
\end{tabular}

\section{RESULTS}

Fourteen informants were men and three were women. In three properties, both sexes participated in the interview. Ages varied from twenty to ninety years old, but $60 \%$ of informants were aged between thirty and fifty.

Among the plant crops cultivated for commercial purposes, 87 plant species were cited, none of which were native from Brazil. For uses other than commercial, there were 115 citations of native species, from which 98 were arboreal. The native trees are classified into 35 ethnospecies (defined according to the perception of respondents), and belong to 30 distinct botanical taxa (Table II). The "jabuticaba" ethnospecies are the main classifications responsible for this numerical difference, due to three different ethnospecies recognized by the informants: jabuticaba, wild jabuticaba, and white jabuticaba, which were all identified botanically as Plinia cauliflora (Mart.) Kausel. Another species, Eugenia uniflora L. has three local names according to the color of the fruits, red, dark purple or almost black. Eugenia involucrata DC. is known both as "cereja do Rio Grande" and just as "cereja". Campomanesia hirsuta Gardner does not have a local name, and is referred to as "unknown fruit". The berry Eugenia candolleana DC. was processed for liqueur and sold by the name "grumixama" usually given to another berry, Eugenia brasiliensis Lam.

The arboreal species cited by informants are representative of 13 botanical families (Table II). Myrtaceae is by far the best represented, with 76 of the 96 citations, followed by Arecaceae with five, Fabaceae with four and Clusiaceae with three citations. The other families had only one citation each. The distribution of the use categories shows that $87.5 \%$ of the native trees are used as food, $4.2 \%$ for attraction of native fauna, $3.1 \%$ both as medicine and human food, $2.81 \%$ for ornamental purposes, $1.0 \%$ both for human and wildlife consumption, $1.0 \%$ exclusively as medicine and $1.0 \%$ both for food and as timber.

In $93 \%$ of the cases, the management practice for the plant species is limited to the collection of its fruits. The use of the trunk, the bark, the exudates, or the ornamental use of the entire plant have $2 \%$ of citations each, while the use of the leaves accounts for $1 \%$. There was only one citation of a native species being used as timber nowadays, 
TABLE II

List of all native arboreal species cited by rural dwellers of the mountain region of Espírito Santo, Brazil, in decreasing order of species use-value (UVs), followed by local names (Ethnospecies), botanical family (Family), biome of occurrence (Biome), use category (Categ), and Origin.

\begin{tabular}{|c|c|c|c|c|c|c|}
\hline Species & Ethnospecies & Family & Biome & Categ & Origin & UVs \\
\hline Plinia sp. & $\begin{array}{c}\text { jabuticaba, jabuticaba- } \\
\text { do-mato, jabuticaba- } \\
\text { branca }\end{array}$ & Myrtaceae & $\mathrm{NC}$ & FO & $\mathrm{P} / \mathrm{G}$ & 0.70 \\
\hline Eugenia uniflora $\mathrm{L}$. & $\begin{array}{c}\text { pitanga, pitanga-preta, } \\
\text { pitanga-roxa }\end{array}$ & Myrtaceae & CE, MA, PP & $\mathrm{FO} / \mathrm{FA}$ & $\mathrm{P} / \mathrm{G}$ & 0.55 \\
\hline $\begin{array}{l}\text { Myrciaria glazioviana } \\
\text { (Kiaersk.) } \\
\text { G.M.Barroso ex } \\
\text { Sobral }\end{array}$ & cabeludinha & Myrtaceae & MA & $\mathrm{FO}$ & $\mathrm{P} / \mathrm{G}$ & 0.45 \\
\hline $\begin{array}{l}\text { Eugenia pyriformis } \\
\text { Cambess. }\end{array}$ & uvaia & Myrtaceae & $\mathrm{CE}, \mathrm{MA}$ & FO & $\mathrm{P} / \mathrm{G}$ & 0.35 \\
\hline $\begin{array}{l}\text { Eugenia involucrata } \\
\text { DC. }\end{array}$ & $\begin{array}{c}\text { cerejeira, } \\
\text { cereja-do-rio-grande }\end{array}$ & Myrtaceae & $\mathrm{CE}, \mathrm{MA}$ & $\mathrm{FO} / \mathrm{FA}$ & G & 0.25 \\
\hline Euterpe edulis Mart. & juçara & Arecaceae & CE, MA & $\mathrm{FO} / \mathrm{O}$ & $\mathrm{F} / \mathrm{P}$ & 0.25 \\
\hline $\begin{array}{l}\text { Campomanesia } \\
\text { guaviroba (DC.) } \\
\text { Kiaersk. }\end{array}$ & guabiroba & Myrtaceae & MA, AM & $\mathrm{FO} / \mathrm{T}$ & $\mathrm{P} / \mathrm{G}$ & 0.20 \\
\hline $\begin{array}{l}\text { Hymenaea courbaril } \\
\text { L. }\end{array}$ & jatobá & $\begin{array}{c}\text { Fabaceae/ } \\
\text { Cesalpinoideae }\end{array}$ & $\begin{array}{l}\text { AM, CA, CE, } \\
\text { MA, PA }\end{array}$ & $\mathrm{FO} / \mathrm{M}$ & $\mathrm{F} / \mathrm{P}$ & 0.20 \\
\hline $\begin{array}{l}\text { Plinia coronata } \\
\text { (Mattos) Mattos }\end{array}$ & jabuticaba-coroada & Myrtaceae & MA & $\mathrm{FO}$ & G & 0.20 \\
\hline $\begin{array}{l}\text { Vasconcellea monoica } \\
\text { A.DC. }\end{array}$ & mamão-ornamental & Caricaceae & $\mathrm{CE}, \mathrm{MA}$ & $\mathrm{O}$ & G & 0.20 \\
\hline $\begin{array}{l}\text { Campomanesia phaea } \\
\text { (O.Berg) Landrum }\end{array}$ & cambuci & Myrtaceae & MA & FO & G & 0.15 \\
\hline $\begin{array}{l}\text { Eugenia stipitata } \\
\text { McVaugh }\end{array}$ & araçá-boi & Myrtaceae & AM & $\mathrm{FO}$ & G & 0.15 \\
\hline $\begin{array}{l}\text { Garcinia brasiliensis } \\
\text { Mart. }\end{array}$ & bacupari & Clusiaceae & MA & FO & G & 0.15 \\
\hline $\begin{array}{l}\text { Plinia edulis (Vell.) } \\
\text { Sobral }\end{array}$ & cambucá & Myrtaceae & M & FO & G & 0.10 \\
\hline $\begin{array}{l}\text { Campomanesia } \\
\text { hirsuta Gardner }\end{array}$ & "unknown fruit" & Myrtaceae & MA & $\mathrm{FO} / \mathrm{M}$ & G & 0.10 \\
\hline $\begin{array}{l}\text { Eugenia brasiliensis } \\
\text { Lam. }\end{array}$ & grumixama & Myrtaceae & MA & FO & G & 0.10 \\
\hline Inga sp. & ingá & $\begin{array}{c}\text { Fabaceae/ } \\
\text { Mimosoideae }\end{array}$ & $\mathrm{NC}$ & FO & $P$ & 0.10 \\
\hline $\begin{array}{l}\text { Vernonanthura } \\
\text { paludosa (Gardner) } \\
\text { H.Rob. }\end{array}$ & assa-peixe & Asteraceae & $\mathrm{AM}, \mathrm{MA}$ & M & $\mathrm{G}$ & 0.10 \\
\hline $\begin{array}{l}\text { Bunchosia macilenta } \\
\text { Dobson }\end{array}$ & vitamina & Malpighiaceae & MA & FA & G & 0.05 \\
\hline $\begin{array}{l}\text { Caryocar brasiliense } \\
\text { Cambess. }\end{array}$ & pequi & Caryocaraceae & $\begin{array}{c}\mathrm{AM}, \mathrm{CA}, \mathrm{CE}, \\
\mathrm{MA}\end{array}$ & FO & G & 0.05 \\
\hline Cordia sp. & piabanha & Boraginaceae & $\mathrm{NC}$ & FA & G & 0.05 \\
\hline $\begin{array}{l}\text { Eugenia candolleana } \\
\text { DC. }\end{array}$ & grumixama, maria-preta & Myrtaceae & $\mathrm{CA}, \mathrm{CE}, \mathrm{MA}$ & $\mathrm{FO}$ & G & 0.05 \\
\hline
\end{tabular}


TABLE II (continuation)

\begin{tabular}{|c|c|c|c|c|c|c|}
\hline Species & Ethnospecies & Family & Biome & Categ & Origin & UVs \\
\hline $\begin{array}{l}\text { Euterpe oleracea } \\
\text { Mart. }\end{array}$ & açaí & Arecaceae & $\mathrm{AM}$ & FO & $\mathrm{P} / \mathrm{G}$ & 0.05 \\
\hline Genipa americana L. & jenipapo & Rubiaceae & $\begin{array}{c}\mathrm{AM}, \mathrm{CA}, \mathrm{CE} \\
\mathrm{MA}, \mathrm{PA}\end{array}$ & FO & G & 0.05 \\
\hline $\begin{array}{l}\text { Lecythis pisonis } \\
\text { Cambess. }\end{array}$ & sapucaia & Lecythidaceae & $\mathrm{AM}, \mathrm{MA}$ & FO & $\mathrm{P} / \mathrm{G}$ & 0.05 \\
\hline $\begin{array}{l}\text { Plinia cauliflora } \\
\text { (Mart.) Kausel }\end{array}$ & jaboticaba-sabará & Myrtaceae & MA & FO & $\mathrm{P} / \mathrm{G}$ & 0.05 \\
\hline $\begin{array}{l}\text { Psidium cattleianum } \\
\text { Sabine }\end{array}$ & araçá & Myrtaceae & $\mathrm{CA}, \mathrm{CE}, \mathrm{MA}$ & FO & G & 0.05 \\
\hline $\begin{array}{l}\text { Psidium guineense } \\
\text { Sw. }\end{array}$ & araçá, araçá-amarelo & Myrtaceae & $\begin{array}{c}\mathrm{AM}, \mathrm{CA}, \mathrm{CE}, \\
\mathrm{MA}, \mathrm{PA}, \mathrm{PP}\end{array}$ & FO & $\mathrm{P} / \mathrm{G}$ & 0.05 \\
\hline $\begin{array}{l}\text { Psidium myrtoides } \\
\text { O.Berg }\end{array}$ & araçaúna & Myrtaceae & CA, MA & FO & $\mathrm{P} / \mathrm{G}$ & 0.05 \\
\hline Psidium sp. & araçá-rugoso & Myrtaceae & $\mathrm{NC}$ & FO & G & 0.05 \\
\hline Annona mucosa Jacq. & beribá & Annonaceae & $\mathrm{AM}, \mathrm{CE}, \mathrm{MA}$ & FO & G & 0.05 \\
\hline $\begin{array}{l}\text { Schinus terebinthifolia } \\
\text { Raddi }\end{array}$ & aroeira & Anacardiaceae & CE, MA, PP & FO & $\mathrm{P}$ & 0.05 \\
\hline
\end{tabular}

Biome: $\mathrm{AM}=$ Amazon, $\mathrm{CA}=$ The Caatinga $\mathrm{CE}=$ The Cerrados, $\mathrm{MA}=$ Atlantic Forest, $\mathrm{PA}=$ The Pantanal, $\mathrm{PP}=\mathrm{The}$ Pampas, $\mathrm{NC}$ $=$ Not Characterized . Categ: $\mathrm{FO}=$ Food, $\mathrm{M}=$ Medicinal, $\mathrm{O}=$ Ornamental, $\mathrm{FA}=$ Fauna Attraction, $\mathrm{T}=$ Timber. Origin: $\mathrm{G}=\mathrm{Garden}$, $\mathrm{P}=$ Plantation, $\mathrm{F}=$ Forest.

Campomanesia guaviroba (DC.) Kiaersk., although three respondents said the use of other native trees as timber was more frequent in the past.

In $51 \%$ of the cases, the fruits are eaten raw, and in $28 \%$, they are consumed as juice, either fresh or frozen. Other common forms of consumption are as jams and jellies (10\%) and as liqueurs (4\%). When native fruits are used to attract wild animals into properties, these are usually birds, such as guan and toucans, and mammals, such as armadillo and peccary. All informants who make such use of plants say they do it merely for the pleasure of having animals around.

The informants get only $2 \%$ of all native timber and non-timber products directly from the forest (Table II). Most native arboreal resources (76\%) are grown in the backyard of the properties, close to the main residence, and $22 \%$ comes from the plantations, where the non-native crops are.

Figure 1 shows the importance of botanical families as expressed by Family Use-values. It shows the relevance of Fabaceae, Arecaceae and
Clusiaceae and the high prevalence of Myrtaceae, both in terms of use diversity and as food sources. All five species with UVs higher than 0.25 in Table II are Myrtaceae (in bold). For this reason, only Myrtaceae species were submitted to the conservation analysis, the results of which are shown in Table III.

Three of the Myrtaceae species cited are endemic to this ombrophilous type of Atlantic Forest of Brazil: Campomanesia hirsuta, Myrciaria glazioviana (Kiaersk.) G.M.Barroso ex Sobral, Plinia cauliflora (Mart.) Kausel. Other three species, Campomanesia phaea (O. Berg) Landrum, Eugenia brasiliensis Lam. and Plinia coronata (Mattos) Mattos, are endemic to the biome Atlantic Forest. The other species are widespread in Brazil, being either native or endemic to Brazil.

Only Campomanesia hirsuta is considered an endangered species and both Campomanesia phaea and Plinia edulis are vulnerable. The other Myrtaceae species do not appear in any of the lists consulted or are listed under "of least concern". 


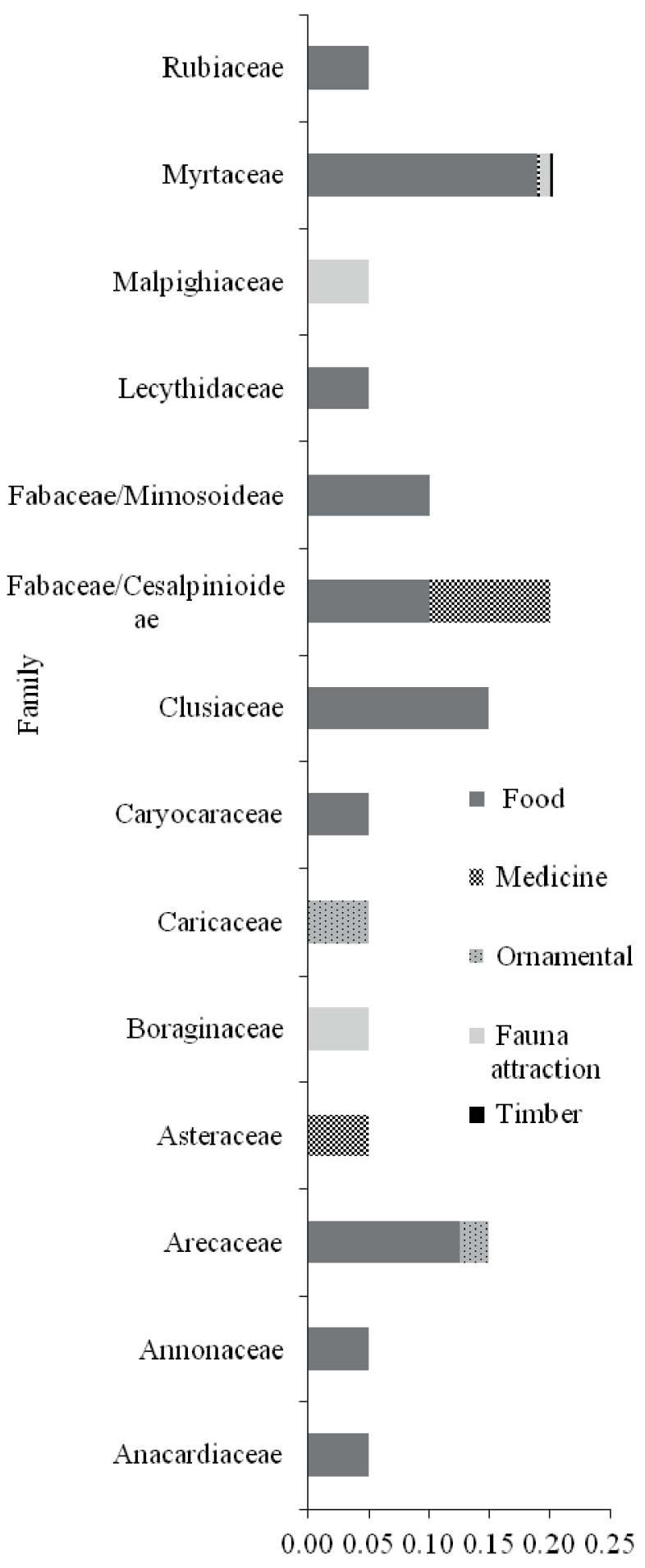

Family Use-values

Figure 1 - The Family Use-values and use categories of native arboreal species employed by rural by dwellers of the mountain region of Espírito Santo, Brazil.
Only Campomanesia guaviroba (DC.) Kiaersk. is harvested in a manner that represents a considerable risk to the species $(\mathrm{H})$, because its use as timber implies the death of the tree as a whole. Local use (L) is high or moderately high for nine out of sixteen species, meaning that most species are used by more than two informants. However, eight species are used for a single purpose as shown by the scores of Use diversity (V). Therefore, according to the methodology, the scores of Use Value (UV) mostly reflect those of Local Use.

Figure 2 summarizes the results of the conservation analysis. It shows that three out of sixteen species are considered of moderate or high Biological Value (above 60 points): Campomanesia hirsuta, Plinia edulis, and Campomanesia phaea, while the other fourteen scored less than 60 points for this criterion. In terms of Use Risk, only Campomanesia guaviroba scored over 85, reflecting Harvesting Risk.

As a result of the overlapping between Biological Value and Use Risk, two species, Campomanesia hirsuta and Plinia edulis, are classified as Category 2 of Conservation Priority, which means they can be harvested moderately. The other fourteen Myrtaceae species are placed in Category 3 and are, therefore, appropriate for harvesting.

\section{DISCUSSION}

The foreign origin of commercial crops grown by the population studied confirms a pattern expected in view of the reality of other Brazilian regions. In spite of that, the use of native trees is superior in terms of species diversity and is mostly represented by edible fruits. Coupling income generating activities with food generating activities is a common practice which minimizes human vulnerabilities to food insecurity (see Hesselberg and Yaro 2006, Giraldi and Hanazaki 2014). The fact that this population, mostly composed of 
TABLE III

List of all native arboreal species of the Myrtaceae family used by rural dwellers of the mountain region of Espírito Santo, Brazil, in decreasing order of Conservation Priority, followed by the score of conservation priority criteria: Distribution (D), Extinction risk (E), Biological value (B), Harvesting risk (H), Local use (L), Use diversity (V), Use Value (UV), Use Risk (UR), and Conservation Priority (CP).

\begin{tabular}{|c|c|c|c|c|c|c|c|c|c|}
\hline Species & (D) & (E) & (B) & (H) & (L) & $(\mathrm{V})$ & (UV) & (UR) & (CP) \\
\hline Campomanesia hirsuta Gardner & 10 & 10 & 100 & 1 & 4 & 2 & 4 & 25 & 62.5 \\
\hline Plinia edulis (Vell.) Sobral & 10 & 7 & 85 & 1 & 7 & 1 & 7 & 25 & 62.5 \\
\hline $\begin{array}{l}\text { Campomanesia phaea (O. Berg) } \\
\text { Landrum }\end{array}$ & 7 & 7 & 70 & 1 & 7 & 1 & 7 & 40 & 55.0 \\
\hline Myrciaria glazioviana (Kiaersk.) G. & 10 & 1 & 55 & 1 & 10 & 1 & 10 & 55 & 55.0 \\
\hline Campomanesia guaviroba (DC.) & 1 & 1 & 10 & 10 & 7 & 2 & 7 & 85 & 47.0 \\
\hline Plinia caulifora (Mart.) Kausel & 10 & 1 & 55 & 1 & 4 & 1 & 4 & 25 & 40.0 \\
\hline Psidium myrtoides O.Berg & 4 & 1 & 25 & 1 & 10 & 1 & 10 & 55 & 40.0 \\
\hline Eugenia brasiliensis Lam. & 7 & 1 & 40 & 1 & 4 & 1 & 4 & 25 & 32.5 \\
\hline Eugenia involucrata DC. & 1 & 1 & 10 & 1 & 10 & 2 & 10 & 55 & 32.5 \\
\hline Eugenia pyriformes Cambess. & 1 & 1 & 10 & 1 & 10 & 1 & 10 & 55 & 32.5 \\
\hline Plinia coronata (Mattos) Mattos & 7 & 1 & 40 & 1 & 4 & 1 & 4 & 25 & 32.5 \\
\hline Psidium cattleianum Sabine & 4 & 1 & 25 & 1 & 7 & 1 & 7 & 40 & 32.5 \\
\hline Psidium guineense $\mathrm{Sw}$. & 1 & 1 & 10 & 1 & 10 & 1 & 10 & 55 & 32.5 \\
\hline Eugenia candolleana DC. & 4 & 1 & 25 & 1 & 4 & 1 & 4 & 25 & 25.0 \\
\hline Eugenia stipitata McVaugh & 1 & 1 & 10 & 1 & 7 & 1 & 7 & 40 & 25.0 \\
\hline Eugenia uniflora L. & 1 & 1 & 10 & 1 & 4 & 2 & 4 & 25 & 17.05 \\
\hline
\end{tabular}

descendents of recent immigrants, displays such a knowledge of native plants might be related to the high biodiversity of the surrounding environment (Hanazaki et al. 2000).

The great importance of the Myrtaceae family is evident from the results. Other ethnobotanical studies in the Atlantic Forest which include herbaceous plants, often show Asteraceae among the families with the highest number of used species (Hanazaki et al. 2000, Lima et al. 2000, Crepaldi and Peixoto 2010). This is due to the high frequency of Asteraceae among medicinal plants. Arboreal species reveal their relevance mainly in the food category, in which Myrtaceae is usually one of the best-represented families, together with Arecaceae and Fabaceae (Hanazaki et al. 2000, Lima et al. 2000, Fonseca-Kruel and Peixoto 2004, Crepaldi and Peixoto 2010). Ethnobotanical studies in Espírito Santo have placed Myrtaceae among the top ten families in terms of usage (Simonelli and Pereira 1994, Albertasse et al. 2010).

Myrtaceae stands out as a very important family of woody plants in several Brazilian vegetation types, with many species that produce edible fruits that are greatly appreciated by both animals and humans (Gressler et al. 2006). Among the Atlantic Forest angiosperms, Myrtaceae is the highest in terms of species number (684) (Stehmann et al. 2009). Saiter et al. (2011) reports a very high species richness of Myrtaceae in the dense ombrophilous forests of the Espírito Santo mountains ( 83 species from a total of 399 species in 1.02 hectares). This would agree in theory with the findings of Christo et al. (2012) of a significant and positive association between the use-value of a given family and its number of species in the surrounding environment.

The medicinal and food categories are often very well represented in ethnobotanical studies 
(B)

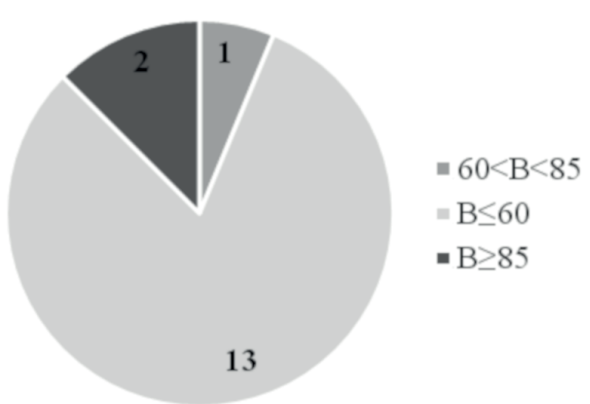

(UR)

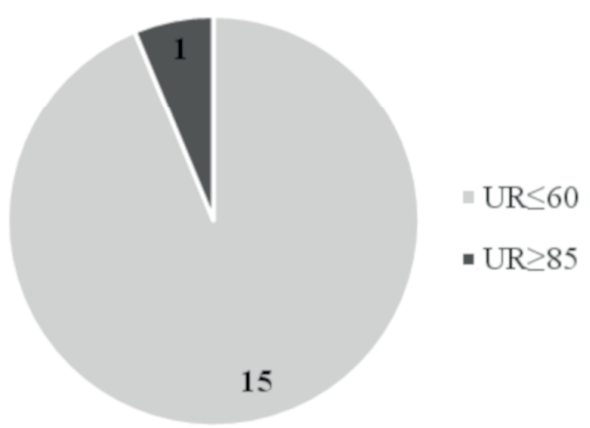

(CP)

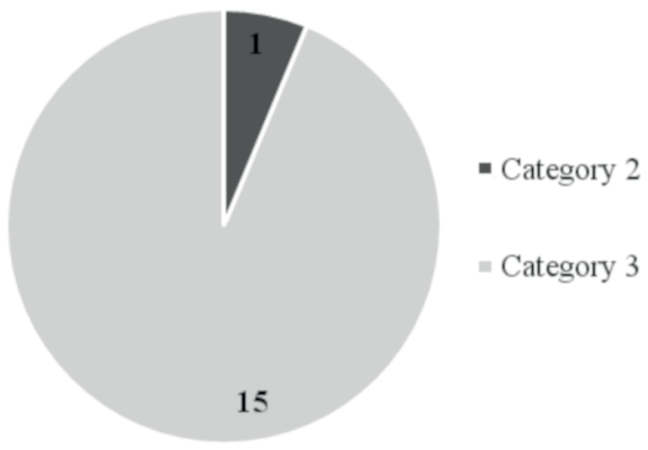

Figure 2 - Scores of Biological Value (B) and Use Risk (UR), as well as categories of Conservation Priority (CP) of the sixteen Myrtaceae species cited by rural dwellers of the mountain region of Espírito Santo, Brazil. in the Atlantic Forest. With the exclusion of herbaceous plants, our study stresses the importance of native trees as sources of food, supporting the findings of Fonseca-Kruel and Peixoto (2004). While other studies show a high number of species being commonly employed for construction and technology (Cruz da Cunha and Albuquerque 2006, Borges and Peixoto 2009, Christo et al. 2012), this often deleterious form of management was not observed to be frequent for our population. The management practices for native species that we encountered are fairly homogeneous and non-destructive, represented in great part by the collection of edible fruits.

No informants reported the harvesting of vegetable material straight from the forest like in Cruz da Cunha and Albuquerque (2006) and Christo et al. (2012). We saw most useful native species being mostly cultivated close to the residence. Three of the informants said that they had used forest resources more regularly in the past, when legal regulations on their use was not as severe as they are nowadays. The high frequency of fauna attraction as a use category finds no parallel in the other studies consulted. It possibly represents a local cultural habit, or alternatively, an old practice of attracting game adapted to a new context of strict legal surveillance.

Seventy-seven Myrtaceae species appear in the most recent version of the national Red List (Martinelli and Moraes 2013). At the State level, eleven species were in the last edition of the list (Simonelli and Fraga 2007). From the species used by our informants, only Campomanesia hirsuta and Plinia edulis, which are endemic to the ombrophilous Atlantic Forest and appear in the Red Lists, require some degree of management limitation.

Campomanesia hirsuta is rare in the Atlantic Forest and, as far as the authors can tell, it has only been registered in Rio de Janeiro and Minas Gerais until the present study. However, our informants 
report collecting fruits and seeds in the nearby forest. This species is used locally both for food and as a medicine, for treating colds and flu, due to a supposed high content of vitamin $\mathrm{C}$. The high degree of endemism allied to biotic pollination and habitat fragmentation are apparently responsible for Campomanesia hirsuta being endangered (World Conservation Monitoring Centre 1998, Martinelli and Moraes 2013).

Plinia edulis is rare in nature, with an estimated population of around ten thousand individuals due to habitat fragmentation has turned it into a vulnerable species (Martinelli and Moraes 2013). Due to its juicy fruit, the presence of Plinia edulis in rural gardens of the Southeast region was frequent in the past, but is rare nowadays. Only two informants in this study had a specimen of Plinia edulis.

There is a little conflict of information regarding the conservation status of Campomanesia phaea when considering national and international sources. The national and more recent source classifies the species as "Low Concern" (CNC FLORA 2012), while it still appears as "Vulnerable" in the IUCN Red List (World Conservation Monitoring Centre 1998). As a matter of caution, we used the most conservative classification. The species occurs both in the ombrophilous and in semidecidous Atlantic forests, but it is rare in nature (Landrum 1986). The fruits are much appreciated locally, but there only two cases of active cultivation in this study. The abundant and juicy fruits are important sources of food for the fauna, including mammals.

The results suggest that, instead of being detrimental to species conservation, the kind of management practiced by this local population might have a positive influence in terms of species reproduction and dispersion. None of the species with medium to high Biological Value were among the 443 arboreal species registered in a forest fragment within the same territory (Saiter and Thomaz 2014). This indicates these fruit trees are rare in nature. Added to the low harvest risk represented by the fruit gathering, the study suggests the relatively sustainable nature of local practices. In fact, that most species were included in Category 3 of Conservation Priority means that, in the local context, they are appropriate for harvesting. Regarding Campomanesia hirsuta and Plinia edulis in Category 2 of Conservation Priority, further measures of conservation and propagation must be adopted.

Food availability and the sustainable use of natural resources are two inseparable subjects on the focus of traditional as well as contemporary societies. The rural dwellers of the forested mountains of Espírito Santo rely mostly on foreign crops commercially, but have learned to complement nutritional needs by consuming native fruits. As a cultural practice, people cultivate the most appreciated fruit trees around their residences, and do not rely on the forest to supply their everyday needs.

Quantitativeethnobotanicalindices havehelped to identify the importance of native species from families such as Arecaceae, Clusiaceae, Fabaceae, while highlighting the predominant importance of the Myrtaceae family. The conservation analysis was useful to highlight the species with higher Biological Value and Conservation Priority, among other aspects. The analysis revealed the low impact of most current management practices, which are quite homogeneous and non-destructive. Under this perspective, the present-day use of native fruits by this population can be regarded as sustainable and even as desirable as it contributes to the maintenance and dissemination of valuable species.

There is a growing commercial interest in the native Myrtaceae. In the last years, more people have learnt to appreciate native flavors and demand new applications. There is a large potential for domestication and genetic improvement. Considering that native species are well adapted to the local environment, low impact forest 
management for seeds collection coupled with the development and proper cultivation practices could bring economic, social and environmental benefits. Studies such as this can collaborate design of public policies encouraging the sustainable management of certain species.

\section{ACKNOWLEDGMENTS}

We would like to thank the Fundação de Amparo à Pesquisa e Inovação do Espírito Santo (FAPES), project number $912 / 2013$, for the financial support in the context of the public notice "Research applied to public policies - Espírito Santo Biodiversity"

\section{REFERENCES}

ALBERTASSE PD, THOMAZ LD AND ANDRADE MA. 2010. Plantas medicinais e seus usos na comunidade da Barra do Jucu, Vila Velha, ES. Rev Bras Plantas Med 12(3): 250-260

ALDANA JP. 2002. Conceptos e importancia de los productos forestales no madereros. Disponível em: <http:// www. forest.ula.ve/ ifla/importanciade-los-productosforestales-no-madereros.html>. Accesso em: 21/05/2012.

BORGES R AND PEIXOTO AL. 2009. Conhecimento e uso de plantas em uma comunidade Caiçara do litoral sul do estado do Rio de Janeiro, Brasil. Acta Bot Bras 23(3): 769779.

CHRISTO AG, GUEDES-BRUNI RR, SOBRINHO PAF, SILVA AG AND PEIXOTO AL. 2012. Evidence for conservation and sustainable use in a fragment of the Atlantic forest in southeastern Brazil by a traditional human group. SpringerPlus 1(1): 21.

CNCFLORA-CENTRONACIONALDE CONSERVAÇÃO DA FLORA. 2012. Campomanesia phaea (O. Berg) Landrum. Disponível em: <http://cncflora.jbrj.gov.br/ portal/>. Acesso em: 15/01/2015.

CREPALDI MOS AND PEIXOTO AL. 2010. Use and knowledge of plants by Quilombolas as subsidies for conservation efforts in an area of Atlantic Forest in Espírito Santo State, Brazil. Biodivers Conserv 19(1): 37-60.

CRUZ DA CUNHA LVF AND ALBUQUERQUE UP. 2006. Quantitative ethnobotany in an Atlantic Forest fragment of the Northeastern Brazil - Implications to conservation. Environ Monit Assess 114: 1-25.

DZEREFOS CM AND WITKOWSKI ETF. 2001. Density and potential utilization of medicinal grassland plants from Abe Bailey Nature Reserve, South Africa. Biodivers Conserv 10: 1875-1896.
FAO - FOOD AND AGRICULTURE ORGANIZATION OF THE UNITED NATIONS. 1995. Non-wood forest products for rural income and sustainable forestry. Roma: FAO, 127 p. (Series Non-Wood Forest Products n. 7).

FAO - FOOD AND AGRICULTURE ORGANIZATION OF THE UNITED NATIONS. 2009. International Treaty on Plant Genetic Resources for Food and Agriculture. Roma: FAO, 56 p.

FEITOZA LR ET AL. 1999. Mapa das Unidades Naturais do Espírito Santo. Mapa na escala 1:400.000. Vitória: EMCAPA.

FONSECA-KRUEL VS AND PEIXOTO AL. 2004. Etnobotânica na Reserva Extrativista Marinha de Arraial do Cabo, RJ, Brasil. Act Bot Bras 18(1): 177-190.

FORZZA RC ET AL. 2010. Angiospermas in Lista de Espécies da Flora do Brasil. Jardim Botânico do Rio de Janeiro. Disponível em: <http://floradobrasil.jbrj.gov.br/2010/ FB000032>. Acesso em: 25/01/2014.

FRISON E. 2011. After Vavilov: collecting germplasm in the 21 st century. In: Guarino L et al. (Eds), Collecting Plant Genetic Diversity: Technical Guidelines, Rome: Biodiversity International. Available at: <http:// cropgenebank.sgrp.cgiar.org/index.php?option=com_co ntent\&view $=$ article\&id=390\&Itemid $=557>$. Accessed January 10, 2017.

FUNDAÇÃO SOS MATA ATLÂNTICA AND INPE. 2012. Atlas dos remanescentes florestais da mata atlântica período 2010-2012. São Paulo. Disponível em: <http:// www.sosmatatlantica.org.br/index.php?section=atlas\&act ion=atlas $>$. Acesso em: 25/11/2014.

GIRALDI M AND HANAZAKI N. 2014. Use of Cultivated and Harvested Edible Plants by Caiçaras What Can Ethnobotany Add to Food Security Discussions? Hum Ecol Rev 20: 51-73.

GRESSLER E, PIZO MA AND MORELLATO LPC. 2006. Polinização e dispersão de sementes em Myrtaceae do Brasil. Rev Bras Bot 29(4): 509-530.

HANAZAKI N, TAMASHIRO JY, HERMÓGENES FL AND BEGOSSI A. 2000. Diversity of plant uses in two Caiçara communities from the Atlantic Forest coast, Brazil. Biodivers Conserv 9: 597-615.

HESSELBERG J AND YARO JA. 2006. An assessment of the extent and causes of food insecurity in northern Ghana using a livelihood vulnerability framework. GeoJournal 67: 41-55

IPEMA - INSTITUTO DE PESQUISAS DA MATA ATLÂNTICA. 2005. Conservação da Mata Atlântica no Estado do Espírito Santo: Cobertura florestal e unidades de conservação. Vitória: IPEMA, 152 p.

IUSS Working Group WRB. 2006. World Reference Base for Soil Resources 2006: a framework for international classification, correlation and communication. Rome: FAO. 128 p. (World Soil Resources Reports 103). 
KINUPP VF AND BARROS IBI. 2010. Agrobiodiversidade nativa, uma riqueza negligenciada: Diversidade de plantas alimentícias não-convencionais (PANCs) na região metropolitana de Porto Alegre. In: Ming LC et al. (Orgs), Agrobiodiversidade no Brasil: Experiências e caminhos da pesquisa, Recife: NUPEEA, p. 163-181.

LANDRUM LR. 1986. Campomanesia, Pimenta, Blepharocalyx, Legrandia, Acca, Myrrhinium, and Luma (Myrtaceae). Flora Neotrop 45: 1-178.

LIMA RX, SILVA SM AND SILVA YSKLB. 2000. Etnobiologia de comunidades continentais da Área de Proteção Ambiental de Guaraqueçaba - Paraná - Brasil. Etnoecológica 4(1): 33-55.

MANDER J, QUINN N AND MANDER M. 1997. Trade in wildlife medicinals in South Africa. Pietermaritzburg: Institute of Natural Resources. (INR Investigational Report N. 154).

MARTINELLI G AND MORAES MA (Orgs). 2013. Livro vermelho da flora do Brasil. Rio de Janeiro: Instituto de Pesquisas Jardim Botânico do Rio de Janeiro, 1100 p.

MINISTRY OF ENVIRONMENT. 2009. Brazilian Forests at a glance - reference period: 2005 - 2009. Brasília: Brazilian Forest Service, $120 \mathrm{p}$.

MITTERMEIER RA, MYERS N, GIL PR AND MITTERMEIER CG. 1999. Hotspots: Earth's Biologically Richest and Most Endangered Terrestrial Ecoregions. Japan: Toppan Printing Co., 430 p.

PEEL MC, FINLAYSON BL AND MCMAHON TA. 2007. Updated world map of the Köppen-Geiger climate classification. Hydrol Earth Syst Sc 11: 1633-1644.

PHILLIPS O AND GENTRY AH. 1993a. The Useful Plants of Tambopata, Peru: I. Statistical Hypotheses Tests with a New Quantitative Technique. Econ Bot 47(1): 15-32.

PHILLIPS O AND GENTRY AH. 1993b. The Useful Plants of Tambopata, Peru: II. Additional Hypothesis Testing in Quantitative Ethnobotany. Econ Bot 47(1): 33-43.

ROSSATO SC, LEITÃO-FILHO H AND BEGOSSI A. 1999. Ethnobotany of Caiçaras of the Atlantic Forest Coast (Brasil). Econ Bot 53(4): 387-395.

SAITER FZ, GUILHERME FAG, THOMAZ LD AND WENDT T. 2011. Tree changes in a mature rainforest with high diversity and endemism on the Brazilian coast. Biodivers Conserv 20(09): 1921-1949.

SAITER FZ AND THOMAZ LD. 2014. Revisão da lista de espécies arbóreas do inventário de Thomaz \& Monteiro (1997) na Estação Biológica de Santa Lúcia: o mais importante estudo fitossociológico em florestas montanas do Espírito Santo. Bol Mus Biol Mello Leitão Nova Sér (Online) 34: 101-128.

SERENO MJCM, WIETHOLTER P AND TERRA TF. 2008. Domesticação de Plantas. In: Barbieri RL and Stumpft ET (Eds), Origem e Evolução de Plantas Cultivadas. Brasília: Embrapa, p. 37-58.

SIMONELLI M AND FRAGA CN. 2007. Espécies da Flora ameaçadas de extinção no estado do Espírito Santo. Vitória: IPEMA, 144 p.

SIMONELLI M AND PEREIRA OJA. 1994. A vegetação de restinga e os índios Tupiniquins da Reserva Indígena de Comboios - Aracruz, ES. Rev Cult Universidade Federal do Espírito Santo 6: 92-106.

STEHMANN JR, FORZZA RC, SALINO A, SOBRAL M, COSTA DP AND KAMINO LHY. 2009. Plantas da Floresta Atlântica. Rio de Janeiro: Instituto de Pesquisas Jardim Botânico do Rio de Janeiro, 516 p.

TARDÍO J AND PARDO-DE-SANTAYANA M. 2008. Cultural Importance Indices: A Comparative Analysis Based on the Useful Wild Plants of Southern Cantabria (Northern Spain). Econom Bot 62(1): 24-39.

UNITED NATIONS. 1992. Full text on the Convention of Biological Diversity. 30 p. Available in: < http://www.cdb. int>. Accessed July 20, 2012.

VELOSO HP, RANGEL-FILHO ALR AND LIMA JCA. 1991. Classificação da vegetação brasileira, adaptada a um sistema universal, v. 6. Rio de Janeiro: Instituto Brasileiro de Geografia e Estatística, 123 p.

WORLD CONSERVATION MONITORING CENTRE. 1998. The IUCN Red List of Threatened Species. Version 2014.3. Available in: < http://www.iucnredlist.org>. Accessed January 26, 2015. 